\title{
Bioactive Compounds from Three Green Algae Species Along Romanian Black Sea Coast with Therapeutically Properties
}

\author{
R. Sirbu \\ T. Negreanu-Pirjol \\ M. Mirea \\ B.S. Negreanu-Pirjol \\ Ovidius" University of Constanta, Faculty of \\ Pharmacy, Constanta, Romania
}

\section{Abstract}

During the past years, it became obvious that the ecosystem presents a marine algae excedent, which should be utilized in one way or another. In the marine world, algae have been intensely studied, but the Black Sea seaweeds are not sufficiently harnessed. To survive in such various diverse and extreme environments, macroalgae produce a variety of natural bioactive compounds and metabolites, such as polysaccharides, polyunsaturated fatty acids, and phlorotannins. In the Black Sea there are three species of green algae: Ulvae lactuca sp., Enteromorpha intestinalis and Cladophora sp. The superior exploitation of the marine biomass represents a highly important resource for the pharmaceutical industry, supplying raw material for the extraction of bioactive substances (vitamins, polysaccharides, sterols, phenols and aminoacids) and various other substances. The purity of this compounds is strongly connected to the state of the marine ecosystem. In the present paper are presented the main bioactive compounds existing in the chemical composition of the green algae in the Black Sea studied. The details of the therapeutic properties of the green algae generated by their chemical compositions.

Keywords: marine biomass, Ulvae lactuca, Cladophora sp., Enteromorpha intestinalis, seaweed, bioactive substances

\section{Introduction}

Green algae have been present in the diet of humans since ancient times and are considered as food and an alternative and rich source of vegetables [1]. They are traditionally consumed in Asia and are also approved for consumption in Europe, namely in France [2]. In fact, the consumption of Ulva poses no threat to human 
health. The Black Sea offers multiple possibilities for capitalizing of green algae on the pharmaceutical field [3]. For the exploitation of marine resources for pharmaceutical purposes, the marine habitats along the Romanian seaside [4, 5], which are free of possible contaminants with coastal pollutants have been studied [6]. The possibilities

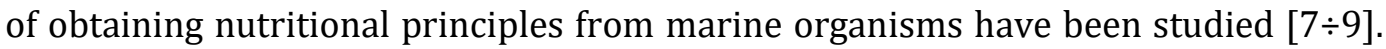
One of the directions for capitalizing on marine resources was the capitalization of marine algae for pharmaceutical purposes $[10 \div 12]$. These algae are rich in soluble and insoluble dietary fibres and important minerals, as well as vitamins, polysaccharides, chlorophyll and protein, and low lipid content. In fact, nutritional interest in algae resides on their wealth on vitamins, oligoelements, minerals and dietary fibres [13]. On the other hand, algae are considered as low-energy food due to their low lipid content and the fact that their carbohydrates are resistant to digestion and fermentation [14]. Besides consumption of algae, one can make use of their constituents for food-related applications. The majority of algal polysaccharides, including ulvan, are resistant to endogenous human digestive enzymes [13], and for this reason, they can be considered as good sources of dietary fibres [15]. These fibres are present in algae in larger quantities compared to land plants and can be divided into water soluble and insoluble fibres [14]. With the increase in eutrophication, marked qualitative changes were recorded in the structure and functionality of macro-phyto-benthos by the end of 2000. Due to the large amount of suspended particles and the growth of plankton, transparency of sea water has undergone remarkable changes. This has contributed to the decline of macrophytes, although there were large amounts of nutrients. Thus, due to the great variability of ecological factors, these changes in the ecosystem and community structure have led to the replacement of some phytocoenoses with others. The consequence was a change in the seasonal and multiannual dynamics of algal communities [16]. Under these conditions, the species of green algae developed: Ulvae sp. (Ulvae lactuca, Enteromorpha intestinalis and Cladophora sp. These macrophytes are usually encountered in the shore area, at depths less than 3 meters, are tolerant to eutrophication [4], [13]. The most common species belong to the genus Ulva and Enteromorpha and exist as a belt of green algae mixed with Cladophora species, in particular [16].

\section{Material and Methods}

\section{Collection of material and drying procedure}

The analyzed material consists of green algae from the following species: Ulvae Lactuca (Linnaeus, 1753) and Enteromorpha intestinalis

(Linnaeus-Nees, 1820) from the Ulvophyceae class, Ulvales order, Ulvaceae family and Cladophora vagabunda (Linnaeus-van den Hoek, 1963), from the Chlorophyceae class, Cladophorales order, Cladophoraceae family, obtained from the coastal waters of the Romanian Black Sea shore. The investigation of the algal biomass of the coastal sector, especially from Vadu, Navodari, Mamaia, and Constanta area (the area with the 
highest density of macrophyte algae), for the characterization of the chemical compositions of coastal seaweeds, throughout the year 2017-2018, was made through sample collecting from the integrated monitoring network that were processed in laboratories, according to the international methodology of vegetable products $[17,18]$. The methods are from botanical phytochemical and physicochemical science. Before starting analysis, algae samples were thawed at $25 \pm 2^{\circ} \mathrm{C}$ ambient temperature. After thawing process, kept at $25 \pm 2^{\circ} \mathrm{C}$ ambient temperature for the following 24 hours, the samples were dried at $40^{\circ} \mathrm{C}$ in drying oven for 24 hours and milled by commercial blender. First, a macroscopic and microscopic study was conducted for each studied algae species.

\section{Determination of total phenolic content and chemical composition of pigments}

Determination of total phenolic content (TPC): Total phenols in U. lactuca samples were estimated spectrophotometrically using Folin-Ciocalteu reagent as described by Singleton et al. [19]. The absorbance was measured at $760 \mathrm{~nm}$ and compared to gallic acid calibration curve.

Determination of total chlorophylls (T-Ch): Three grams of U. lactuca samples was homogenized in acetone $(30 \mathrm{ml}, 80 \%)$ and incubated overnight in dark at $4^{\circ} \mathrm{C}$ for complete extraction followed by centrifugation at 10,000 $\mathrm{xg}$ for $5 \mathrm{~min}$. Total chlorophyll (T-Chl), chlorophyll a ( $\mathrm{Chl} \mathrm{a}$ ) and chlorophyll b (Chl b) in the supernatant were determined spectrophotometrically at wavelength $664 \mathrm{~nm}$ according to Lichtenthaler method [20].

Determination of total carotenoids (TCAR): The total carotenoids were determined spectrophotometrically at $450 \mathrm{~nm}$ according to AOAC [21].

$\beta$-carotene was used as a standard.

\section{The phytochemical studies}

The analysis were carried out in the laboratories of the Pharmacy Faculty of Ovidius University of Constanta.

Out of the vegetal sample sprinkled with a non-polar solvent (ethilic ether, petroleum ether, benzen, hexan, clorophorm etc), then with a medium polarity solvent (ethanol, methanol) and only in the ned with water, the following fractions were obtained,[10]:

1. etheric extractive solution (A);

2. alcoholic extractive solution (B);

3. water based extractive solution (C).

Each extract is the analyzed for the identification of the active principles of pharmaceutical interest. For the identification of the chemical compounds of the three extracts, they are analyzed separately, using the methods fit for the physical and chemical properties of each group of active principles. In the etheric extract we can 
identify lipophyl chemical compounds, and in the other two extracts hydrophyl chemical compounds. The study material was represented by the collected vegetal products: Ulvae Lactuca (syn. Ulvae Rigida), Enteromorpha intestinalis and Cladophora sp.

\section{Nutritional composition analysis}

Seasonal crude protein [22], crude lipid [23], moisture [21], ash [23], carbohydrate ,

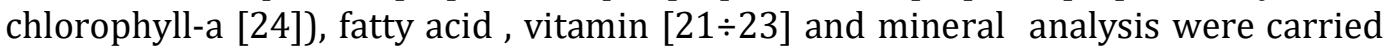
out for dried green seaweeds [25]. All analysis were carried out with dry material since the products were going to be prepared as dried material.

\section{Results and Discussions}

In order to have a complete construction of seaweed biomass, a brief discussion is required on the main representatives of the three green marine algae species The results of the macroscopic and microscopic examination for the green algae species harvested from the Black Sea are presented in Tables 1 and 2. The species of the Ulvae genus, as well as those of the Enteromorpha genus, are generally among the first species of macroalgae that colonize the substrate in the littoral areas with nutrientrich waters. This success can be attributed to their simple morphology as well as to the remarkable reproductive capacity, which in turn may be due, at least in part, to the photosynthetic capacity of their reproductive cells. The photosynthetic capacity of spores and gametes leads to germination and then to rapid growth and development from the moment of fixation on the substrate.

Table 1. The macroscopic examination of the green seaweeds $[10,11]$

\begin{tabular}{|c|c|c|}
\hline Ulvae lactuca (syn. Ulvae rigida) & $\begin{array}{l}\text { Enteromorpha } \\
\text { intestinalis }\end{array}$ & Cladophora Vagabunda \\
\hline $\begin{array}{l}\text { green algae with a dark green to } \\
\text { pale green thalle; } \\
\text { the height of the thalle - between } \\
5-30 \mathrm{~cm} \text {; } \\
\text { rizoid with the aspect of firm dark } \\
\text { brown strings; } \\
\text { extremely short cauloid; } \\
\text { filoid with the aspect of a leafy } \\
\text { irregular blade, sometimes with } \\
\text { breaks in the middle; } \\
\text { in the inferior part of the thalle, } \\
\text { there are fine marginal extensions, } \\
\text { visible with a magnifying glass. }\end{array}$ & $\begin{array}{l}\text { green } \\
\text { multimulticellular alga, } \\
\text { with a } \\
\text { single-cell layer tale } \\
\text { height - from a few cm } \\
\text { to } 1 \mathrm{~m} \text {, } \\
\text { width - from } 1 \mathrm{~mm} \text { to } 10 \\
\mathrm{~cm} \text {; } \\
\text { disk-like rhizoid; } \\
\text { short, cylindric cauloid; } \\
\text { intestine-like filoide. }\end{array}$ & $\begin{array}{l}\text { Multiannual alga, 10-15 } \\
\text { cm tall; } \\
\text { Strong discoidal rhizoid; } \\
\text { Filamental tale with } \\
\text { ramifications, } \\
\text { Bushy aspect; } \\
\text { Filaments formed of long } \\
\text { continuous cells; } \\
\text { Terminal ramifications in } \\
\text { groups of } 4-6 \text {, bent as a } \\
\text { sickle. }\end{array}$ \\
\hline
\end{tabular}

The morphological characteristics of these marine plants are highlighted. 
Table 2. The microscopic examination of the green seaweeds $[10,11]$

\begin{tabular}{|c|c|c|}
\hline $\begin{array}{l}\text { Ulvae lactuca } \\
\text { rigida) }\end{array}$ & Enteromorpha intestinalis & Cladophora vagabunda \\
\hline $\begin{array}{l}\text { The cells are placed into } \\
\text { ordinate rows, are rounded or } \\
\text { long, } \\
\text { only one nucleus and a large } \\
\text { chromatophore located } \\
\text { towards the exterior of the cell, } \\
\text { with a board like aspect and } \\
\text { with 1-2 pyrenoids. }\end{array}$ & $\begin{array}{l}\text { The cells are arranged } \\
\text { without a special order, } \\
\text { instead of being grouped in } \\
\text { visible rows. } \\
\text { In the cell there is a single } \\
\text { large plate-shaped } \\
\text { chromatophore that does } \\
\text { not fill the cell but a single } \\
\text { pyrenoid. }\end{array}$ & $\begin{array}{l}\text { The cells have thick } \\
\text { membranes with a } \\
\text { lamellar structure, } \\
\text { In the cells there is a cross- } \\
\text { linked parietal } \\
\text { chromatophorer with } \\
\text { many pyrenoids. }\end{array}$ \\
\hline
\end{tabular}

Table 3 presents the results obtained for the chemical compositions of the studied marine algae. Literatures are also selected. There is a good consistency with the literature data of other researchers who have worked on green seaweed.

Table 3 Crude Chemical Composition of green algae from Black Sea

\begin{tabular}{|c|c|c|c|c|}
\hline Parameter & $\begin{array}{l}\text { Ulvae } \\
\text { lactuca }\end{array}$ & $\begin{array}{l}\text { Enteomorpha } \\
\text { intestinalis }\end{array}$ & $\begin{array}{l}\text { Cladophora } \\
\text { vagabunda }\end{array}$ & $\begin{array}{l}\text { Literature data } \\
\text { values / References }\end{array}$ \\
\hline Moisture (\%) & $12,86 \pm 1,01$ & $9,14 \pm 2,93$ & $5,71 \pm 0,22$ & $6.80[13] ; 12.60[24]$ \\
\hline Ash (\%) & $18,38 \pm 3,08$ & $30,28 \pm 9,01$ & $26,38 \pm 0,31$ & $\begin{array}{l}19.59[26] ; 21.3-22.8 \\
{[27] ; 12.4-29.9[24]}\end{array}$ \\
\hline Sulphates (\%) & $68,86 \pm 1,99$ & $60,57 \pm 6,12$ & $67,92 \pm 0,53$ & $65.3-70.5[25]$ \\
\hline $\begin{array}{ll}\text { Total } & \text { nitrogen } \\
(\%) & \end{array}$ & $2,32 \pm 0,20$ & $1,94 \pm 0,14$ & $2,45 \pm 0,02$ & - \\
\hline Protein (\%) & $14,58 \pm 1,30$ & $12,10 \pm 0,89$ & $15,43 \pm 0,36$ & $\begin{array}{l}8.46[13] ; 17[24] ; 27.2 \\
{[26]}\end{array}$ \\
\hline Lipid (\%) & $0,69 \pm 0,06$ & $1,690,47$ & $3,85 \pm 0,47$ & $\begin{array}{l}7.87[13] ; 1.5-3.6 \quad[24] \\
0.3[26]\end{array}$ \\
\hline $\begin{array}{l}\text { Carbohydrate } \\
(\%)\end{array}$ & $\begin{array}{l}54,95 \\
\pm 1,43\end{array}$ & $46,57 \pm 5,19$ & $48,45 \pm 0,5$ & $59.10[13] ; 61.50[24]$ \\
\hline $\begin{array}{l}\text { Total dietary } \\
\text { fiber (\%) }\end{array}$ & $59.50 \pm 2.15$ & $52.36 \pm 3.26$ & $61.56 \pm 1,5$ & $\begin{array}{l}54.90 \quad[13] ; \quad 50.3-55.4 \\
{[27] ; 60.50[26]}\end{array}$ \\
\hline Insoluble fiber & $33.59 \pm 3.25$ & $31.54 \pm 1.58$ & $38.64 \pm 2.68$ & $34.37[13] ; \quad 24.2-32.6$ \\
\hline
\end{tabular}




\begin{tabular}{|l|l|l|l|l|}
\hline$(\%)$ & & & & {$[27] ; 33.30[26]$} \\
\hline Soluble fiber (\%) & $25.91 \pm 1.25$ & $20.82 \pm .0 .56$ & $22.92 \pm 1.66$ & $\begin{array}{l}20.53[14] ; 15.8-8.0 \\
{[13] ; 27.20[26]}\end{array}$ \\
\hline
\end{tabular}

All values show mean of three replicates, \pm standard deviation

Total phenolics compounds (TPC) and pigments

As shows in Table 4, the amounts of total phenolics compounds (TPC), total chlorophyll (T-Chl), Chl a, Chl b and total carotenoids (TCAR).

Phenolic compounds are characterized by aromatic ring with hydroxyl groups. Aromatic ring with one or two hydroxyl groups are defined as simple phenols, such as benzoic acids and hydroxycinnamic, and their derivates also have been found in algae. Polyphenols are characterized by the presence of a number of phenol units. The characteristic and number of the phenol structural units determine the unique chemical, physical, and biological properties of particular polyphenols class, such as phloroglucinols and phlorotannins. Based on the inter-linkage, phlorotannins can be further subdivided into some groups such as phloroglucinol, eckol and dieckol [28]. In recent years, phenolic compounds derived from marine algae have been explored with a broad spectrum of beneficial bioactivity, such as anticancer, antioxidant, antimicrobial, anti-inflammatory activities, and the antioxidant activity.

As photosynthetic organisms, algae can synthesize three kinds of pigments: chlorophylls, carotenoids and phycobiliproteins [28]. The pigments in algae determines the color of algae. The green color is caused by the presence of chlorophylls a and b. As photosynthetic organisms, algae can synthesize three kinds of pigments: chlorophylls, carotenoids and phycobiliproteins [28]. The pigments in algae determines the color of algae. The green color is caused by the presence of chlorophylls $\mathrm{a}$ and $\mathrm{b}$.

Table 4 Chlorophylls (Chl), carotenoids and phenolic compounds contents and yield of organic extracts of green algae from Vadu-Constanta area

\begin{tabular}{|l|l|l|l|l|l|}
\hline Sample & $\begin{array}{l}\text { Chl a } \\
\mathrm{mg} / \mathrm{g} \text { d.w }\end{array}$ & $\begin{array}{l}\text { Chl b } \\
\mathrm{mg} / \mathrm{g} \text { d.w }\end{array}$ & $\begin{array}{l}\text { Total Chl. } \\
\mathrm{mg} / \mathrm{g} \mathrm{d.w}\end{array}$ & $\begin{array}{l}\text { Total } \\
\text { carotenoids } \\
\mathrm{mg} / \mathrm{g} \text { d.w }\end{array}$ & $\begin{array}{l}\text { Total } \\
\text { phenolic } \\
\text { TPC } \\
\text { (mg. } \\
\text { GAE/100g } \\
\text { d.w.) }\end{array}$ \\
\hline Ulvae lactuca (L.) & $19.16 \pm 2.69$ & $4.07 \pm 0.36$ & $23.23 \pm 0.67$ & $9.97 \pm 0.85$ & $285.5 \pm 0.6$ \\
\hline $\begin{array}{l}\text { Enteromorpha } \\
\text { intestinalis (L.- } \\
\text { Ness) }\end{array}$ & $16.74 \pm 1.65$ & $4.23 \pm 0.45$ & $20.97 \pm 1.67$ & $12.73 \pm 1.32$ & $268.8 \pm 0.7$ \\
\hline
\end{tabular}




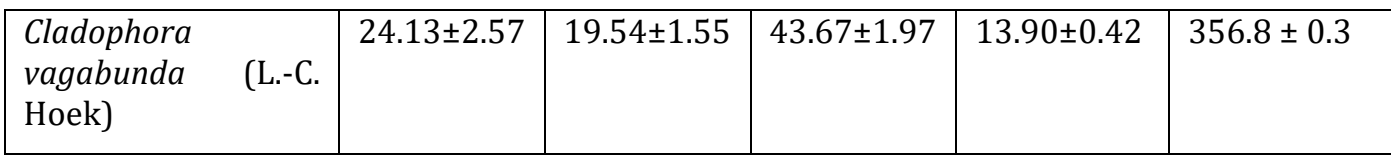

All values show mean of three replicates, \pm standard deviation

\section{Chemical Composition in active principle from green Seaweeds}

Out of the vegetal sample sprinkled with a non-polar solvent (ethilic ether, petroleum ether, benzen, hexan, clorophorm etc), then with a medium polarity solvent (ethanol, methanol) and only in the ned with water, the following fractions were obtained, [10]: (A) etheric extractive solution, (B) alcoholic extractive solution, (C) water based extractive solution. Each extract is the analyzed for the identification of the active principles of pharmaceutical interest. For the identification of the chemical compounds of the three extracts, they are analyzed separately, using the methods fit for the physical and chemical properties of each group of active principles. In the etheric extract we can identify lipophyl chemical compounds, and in the other two extracts hydrophyl chemical compounds. As a follow up of the identification reactions previously discussed, the following results were obtained, summarized in Table 5.

Table 5 The selective reactions used in chemical analysis and identified active principles from seaweeds

\begin{tabular}{|l|l|l|}
\hline $\begin{array}{l}\text { Analyzed } \\
\text { solution }\end{array}$ & Reactions used & Identified active principles \\
\hline Etheric extracts & Lieberman-Burchard & Steroles and triterpenes \\
\cline { 2 - 3 } & Fluorescent UV. $(\lambda=365 \mathrm{~nm}$ & Cumarines \\
\hline \multirow{4}{*}{$\begin{array}{l}\text { Alcoholic } \\
\text { extracts }\end{array}$} & Iron Chlorure reaction & Catehic Tanin \\
\cline { 2 - 3 } & Fehling & Reducing compounds \\
\cline { 2 - 3 } & Liebermann Bourchard & Triterpenic heterozides \\
\cline { 2 - 3 } & Borntrager & Antracenozide \\
\cline { 2 - 3 } & UV $(\lambda=365 \mathrm{~nm})$ & Reducing compounds \\
\hline \multirow{3}{*}{$\begin{array}{l}\text { Water } \\
\text { extracts }\end{array}$} & Fehling & Ozes and poliozes \\
\cline { 2 - 3 } & H2SO4 conc. + tymol & Soapozides \\
\cline { 2 - 3 } & Foaming & Fatehic tanin \\
\cline { 2 - 3 } & FeCl3 & \\
\hline
\end{tabular}

\section{Green algae composition in vitamins [12]}

The maximum vitamin A $(0.158 \pm 2.56 \mathrm{mg} / 100 \mathrm{~g})$ in Enteromorpha intestinalis and vitamin $E(8.132 \pm 1.03 \mathrm{mg} / 100 \mathrm{~g})$ in Cladophora vagabunda, in amounts were no 
detected, the statistically significant difference between other seasons $(P>0.05)$. While there was no difference statistically $(\mathrm{P}>0.05)$ between seasons in terms of vitamins, the highest C value were observed in Ulvae lactuca $(143.461 \pm 0.35 \mathrm{mg} / 100 \mathrm{~g}$ ) and Enteromorpha $(120.516 \pm 0.85 \mathrm{mg} / 100 \mathrm{~g})$ and B3 vitamins were in the highest amounts in Cladophora sp. (Table 6).

Table 6. Results of vitamin analysis obtained seasonally

\begin{tabular}{|l|l|l|l|}
\hline Sample & $\begin{array}{l}\text { Ulvae lactuca } \\
\text { (Linneus) } \\
\mathrm{mg} / 100 \mathrm{~g}\end{array}$ & $\begin{array}{l}\text { Enteromorpha } \\
\text { intestinalis } \\
\text { (L.-Ness) } \\
\mathrm{mg} / 100 \mathrm{~g}\end{array}$ & $\begin{array}{l}\text { Cladophora } \\
\text { vagabunda } \\
\text { (L.-C Hoek) } \\
\mathrm{mg} / 100 \mathrm{~g}\end{array}$ \\
\hline Vitamin A (Retinol) & $0.142 \pm 0.88$ & $0.158 \pm 2.56$ & $0.151 \pm 1.83$ \\
\hline $\begin{array}{l}\text { Vitamin B1 } \\
\text { (Thiamine) }\end{array}$ & $0.175 \pm 0.12$ & $0.125 \pm 0.25$ & $0.153 \pm 0.02$ \\
\hline $\begin{array}{l}\text { Vitamin B2 } \\
\text { (Riboflavin) }\end{array}$ & $0.992 \pm 0.06$ & $0.973 \pm 0.01$ & $0.893 \pm 0.16$ \\
\hline Vitamin B3 (Niacin) & $0.965 \pm 0.15$ & $0.816 \pm 0.12$ & $2.495 \pm 0.19$ \\
\hline $\begin{array}{l}\text { Vitamin B6 } \\
\text { (Pyridoxine) }\end{array}$ & $0.258 \pm 0.02$ & $0.227 \pm 0.02$ & $0.189 \pm 0.01$ \\
\hline $\begin{array}{l}\text { Vitamin C (Ascorbic } \\
\text { acid) }\end{array}$ & $143.461 \pm 0.35$ & $120.516 \pm 0.85$ & $89.665 \pm 2.58$ \\
\hline $\begin{array}{l}\text { Vitamin E } \\
\text { (Tocopherol) }\end{array}$ & $7.919 \pm 0.11$ & $6.935 \pm 1.03$ & $8.132 \pm 1.03$ \\
\hline
\end{tabular}

Values were given as average and \pm standard deviation of 3 paralleled analysis.

The content in minerals of green algae $[10,11]$

According to mineral contents investigated in the study, calcium was observed with the maximum contents compared to other minerals. The maximum calcium content $(1620.35 \pm 2.55 \mathrm{mg} / \mathrm{kg})$ was obtained in Ulvae lactuca. Microminerals were obtained in this order; $\mathrm{K}>\mathrm{Fe}>\mathrm{Mn}>\mathrm{Sr}>\mathrm{Mg}>\mathrm{Zn}>\mathrm{Cu}$ (Table 7).

Table 7. Results of studied mineral analysis

\begin{tabular}{|l|l|l|l|}
\hline $\begin{array}{l}\text { Mineral Type } \\
\text { in Sample }\end{array}$ & Ulvae lactuca & $\begin{array}{l}\text { Enteromorpha } \\
\text { intestinalis }\end{array}$ & $\begin{array}{l}\text { Cladophora } \\
\text { vagabunda } \\
\end{array}$ \\
& (Linneus) & (L.-Ness) & (L.-C Hoek) \\
& $\mathrm{mg} / \mathrm{kg}$ & $\mathrm{mg} / \mathrm{kg}$ \\
\hline
\end{tabular}




\begin{tabular}{|l|c|c|c|}
\hline $\mathrm{Fe}$ & $340.15 \pm 0.88$ & $315.27 \pm 2.13$ & $330.56 \pm 1.95$ \\
\hline $\mathrm{Cu}$ & $4.34 \pm 0.16$ & $4.86 \pm 0.51$ & $5.03 \pm 0.56$ \\
\hline $\mathrm{Zn}$ & $19.46 \pm 0.85$ & $14.45 \pm 0.18$ & $6.75 \pm 0.25$ \\
\hline $\mathrm{Mn}$ & $85.76 \pm 1.95$ & $90.25 \pm 0.98$ & $80.33 \pm 1.34$ \\
\hline $\mathrm{Ca}$ & $1620.35 \pm 2.55$ & $1580.15 \pm 2.96$ & $1495.64 \pm 2.87$ \\
\hline $\mathrm{Mg}$ & $79.15 \pm 1.25$ & $78.56 \pm 1.06$ & $81.65 \pm 0.84$ \\
\hline $\mathrm{K}$ & $956.54 \pm 2.03$ & $1055.64 \pm 2.96$ & $920.56 \pm 1.67$ \\
\hline $\mathrm{Sr}$ & $80.23 \pm 1.06$ & $81.65 \pm 2.14$ & $82.66 \pm .95$ \\
\hline
\end{tabular}

Values were given as average and \pm standard deviation of 3 paralleled analysis.

Polysaccharides content of green algae

Various reports are available in determining the structural composition of green algae polysaccharides and the composition is variable. In a chemico-enzymatic degradation study, rhamnose, glucose, galactose, xylose and glucuronic acid were the constitutive sugars detected upon complete hydrolysis. Chemical hydrolysis of ulvan (polysaccharides) showed about $2 \%$ (dry weight) of ulvanobiouronic acid ( $\beta$-D-GlcA$(1,4)$-L-Rha). However, the additional hydrolysis by purified $\beta$-D-glucuronidase resulted in the degradation of ulvanobiouronic acid into glucuronic acid and rhamnose. So by this method of chemico-enzymatic analysis helped in estimating the acidic and neutral sugars, especially the iduronic acid in this sulfated polysaccharides [29]. Ulvan from Ulvae lactuca was chemically composed of $47 \%$ total carbohydrates, $23.2 \%$ uronic acids, $29.9 \%$ ash, $17.1 \%$ sulfate groups and $1.0 \%$ N2 [30]. Gas chromaotographic (GC) analysis indicated the presence of main neutral sugars namely: glucose, rhamnose and xylose, with the smaller fractions of arabinose, galactose and mannose. Further analysis using 13C-NMR (Nuclear Magnetic Resonance) and FTIR (Fourier Transform Infrared Spectroscopy) indicted that the repeating units are ( $\alpha$-L-IdopA-(1 4)- $\alpha$-L-Rhap 3S) and ( $\beta$-D-GlcpA-(1 4)- $\alpha$-L-Rhap 3S) (Fig.1). By seaweed histology method (Alcian blue staining) sulfated polysaccharides presence was authenticated, while the chemical composition was found in the order of total sugar (65.4\%), uronic acid (17.2\%) and sulfate contents (17.4\%) [31]. A rapid determination method of U. lactuca cell wall composition was reported using FTIR [32]. GC analysis showed that rhamnose was the main component of structure, while variable contents of glucose and fucose with traces of galactose, mannose and xylose were also observed [33]. 


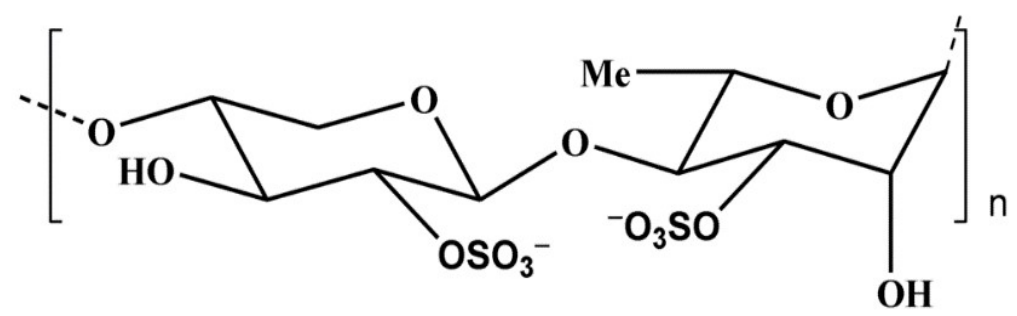

$$
\mid \rightarrow 4)-\beta-D-X y \mid 2 S(1 \rightarrow 4)-\alpha-L-R h a 3 S(1 \rightarrow]
$$

Fig.1Structural repeating units of main disaccharide in Ulva sp. [34]

\section{Lipids, fatty acids and sterols}

Algae lipids consist of glycolipids, phospholipids and non-polar glycerolipids (neutral lipids) [35]. Phospholipids are characterized by the presence of a phosphate group at sn-3 position. The main phospholipids derived from algae include phosphatidylglycerol (PG), phosphatidylcholine (PC), phosphatidylethanolamine (PE), phosphatidylserine (PS), phosphatidylinositol (PI) [36].

Fatty acids (FA) are carboxylic acids with long aliphatic chains which may be straight or branched, saturated or unsaturated (Mohan et al., 2015). The carbon number of natural FAs is usually even (C4-C28), however, odd chain FAs also exist in algae. According to the number of double bonds, FAs are divided into monounsaturated fatty acids (MUFAs, with one double bond) and polyunsaturated fatty acids (PUFAs, with more than 2 double bonds) [37]. Oxylipins are the oxygenated products derived from PUFAs which exhibit innate immunity in response to environmental stress such as wound, metal toxicity and pathogenic bacteria.

Sterols are the important structural components of cell membranes which can regulate membrane permeability and fluidity. The basic structure of sterol is composed of four rings (A, B, C, D) and with a hydroxyl group at C3, two methyl groups at C18 and C19, and a side chain at C17.

\section{Biomedical applications}

Considering the advantages of cheaper origin, abundant availability and low toxicity with cytocompatibility suggests to broaden the ulvans applications. Other than antioxidant, anti-inflammation, immune-modulation, antitumor and anticoagulant potential, attempts have been made to extrapolate ulvans in biomedical applications (Table 6). There are certain compounds in seaweeds, such as lectins, alkaloids, terpenes, and halogenated compounds. These bioactive compounds isolated from marine algae have been reported with antibacterial, anti-inflammatory, antioxidant, anti-tumor activity, and thus have great prospects in the food, pharmaceutical, cosmeceutical, and nutraceutical industries [38]. Here we will focus on the potential 
applications of marine algae on dermatology symptoms including UV protection, skin whitening and melanoma treatments.

Table 6 Summary of relevant biological activities associated with ulvan and its potential strategic application in a pharmaceutical context, according to diverse studies reported in the literature

\begin{tabular}{|c|c|c|}
\hline Biological activity & Strategic possible applications & References \\
\hline Anti-viral & $\begin{array}{l}\text { Treatment of viral infections, particularly } \\
\text { influenza and HSV-1 }\end{array}$ & [39] \\
\hline Anti-oxidant & $\begin{array}{l}\text { Prevention of oxidative stress and be used } \\
\text { as a protective drug for several } \\
\text { pathologies, including age-related or } \\
\text { cancer }\end{array}$ & $\begin{array}{ll}{[40,} & 41, \\
42,43]\end{array}$ \\
\hline Anti-coagulant & Surrogate of heparin & {$[39,43,44]$} \\
\hline Anti-hyperlipidemic & Regulation of lipid metabolism & {$[1,2,43,44]$} \\
\hline Immunostimulating & $\begin{array}{l}\text { Therapy for diseases where the immune } \\
\text { system is impaired }\end{array}$ & {$[43, \div 45]$} \\
\hline $\begin{array}{l}\text { Anti-proliferative towards } \\
\text { cancer cells }\end{array}$ & $\begin{array}{l}\text { Agent for inhibition of cancer cells } \\
\text { proliferation }\end{array}$ & [39] \\
\hline
\end{tabular}

\section{Anti-oxidant activity}

Antioxidants are crucially important, industrial chemicals widely used in food preservation and pharmaceuticals [40]. Moreover, utilization of synthetic antioxidants in pharmaceutical drugs is accompanied with toxicity and danger to human health [41]. Among natural resources seaweeds are efficient inhibitors of oxidation process without any side effects $[41,42]$. Antioxidants are very important in regulating the oxidative stress related diseases in human. In this instance marine green algae have been explored and found to possess a broad spectrum of strong antioxidant activity.[46] evaluated the native and modified ulvans antioxidant activity. Ulvan are the sulfated heteropolysaccharides obtained from Ulva sp. of Chlorophyta. Sulfate contents of ulvan was modified (19.5-32.8\%) using sulfur trioxide/N, N-dimethyl formamide. Antioxidant power was assessed in terms of scavenging activity of hydroxyl and superoxide radicals, reducing power assay and metal chelating potential. All the studied parameters of antioxidant characterization were better indicted after improving the sulfate groups, i.e. better scavenging activity, stronger reducing power and more pronounced chelating ability. It was suggested that the natural ulvan already have sulfates but by increasing the number of sulfate 
radicals in the polymers stronger antioxidant potential was observed. According to Iftikhar et al. [47], the bioactive compounds that are responsible for restraining oxidation processes also lead to cardiovascular health. Cladophora produces a wide range of secondary metabolites with significant antioxidant potential, such as tocopherol [48], carotenoids [49], polyphenols [50]. Additional studies have shown the antioxidant potential of Cladophora species. Laungsuwon and Chulalaksananukul [51] studied free radical scavenging activity of an ethyl acetate extract of C. glomerata in terms of hydrogen donating or radical scavenging ability through the stable radical 1, 1-diphenyl-2-picrylhydrazyl (DPPH). Results (49.8 $\pm 2.7 \%$ DPPH scavenging at $100 \mathrm{~g} / \mathrm{ml}$ ) illustrated the free radical neutralization potential of C. glomerata

\section{Anti-diabetic activity}

Insufficient secretion of insulin in target cells causes the disease diabetes mellitus (DM). It is a set of metabolic disorders characterized by hyperglycemic condition and altered lipid and protein metabolism [52]. The World Health Organization estimated that around 300 million will be suffering by diabetes by the year 2025 [53] and this disorder would rank 7-th by 2030 for causing mortalities [54]. Synthetic drugs do not permanently cure DM and they are associated with adverse side effects. Alternative, natural and safe hypoglycemic agents are needed. Green plants and algae are well suited for this purpose, because they contain effective antidiabetic agents, such as glycosides, alkaloids, terpenoids, flavonoids, and carotenoids [52]. The mechanism behind their anti-hyperglycemic potential may either include pancreatic cells repair that triggers insulin production or inhibition of glucose absorption by intestine.

\section{Anti-coagulant activity}

Anticoagulants are especially used in medication to prevent the clotting of blood. Many oral coagulants are available these days. Various anticoagulant substances are also used in blood sampling equipment. Since the start of 21-st century numerous new agents have been recognized and introduced, and referred as the directly acting oral anticoagulants. A similar attempt was made by [33], and found that the anti-coagulant property of the purified polysaccharides from Ulva sp. Hot water extraction and ethanol was used in extraction process while for purification ion exchange and HPLC were used. Anticoagulant properties were tested in vitro by determining the thromboplastin-activation time of human plasma, and was compared with heparin. A considerable anticoagulant activity was observed. It was suggested that sulfated polysaccharides inhibited the thrombin activity directly and also by the potentiation of heparin cofactor II (HCII). The biosynthesis of the sulphated, water-soluble polysaccharides, xylogalatoarabinans, is reported in cell walls of Cladophora sp., which has blood anticoagulant activity. The possible mechanism of blood anticoagulation is by thrombin inhibition $[55,56]$. The nanocellulose of Cladophora, which has a large surface area and high crystalline nature, was subjected to chemical modifications to produce a novel anticoagulant [56]. The Cladophora nanocellulose were transformed to a sulphonated nanocellulose ranging from 1 to $100 \mu \mathrm{m}$ in 
diameter that could be used instead of heparin as nontoxic anticoagulants during blood purification for kidney patients [57].

\section{Anti-inflammatory}

Awad (2000) isolated a biologically active steroid (3-0- $\beta$-D-glucopyranosyl clerosterol) from $U$. lactuca [58]. The isolated extract was tested against antiinflammatory assay namely, mouse ear oedema, where the phorbol derivatives were used to induce oedema ( $5 \mathrm{mg} / \mathrm{ear}$ ). This extract could be a promising antiinflammatory agent. Similarly, green macroalgae Ulvae lactuca was tested in rat model to protect the oedema by reducing the inflammation. Moreover, the elite organs were examined microscopically, and no alteration was seen in the positive control and treated ones.

The methanolic and chloroform extracts of seaweeds (Cladophora sp.,) were tested for the anti-inflammatory effects on mouse carrageenan edema and mouse ear edema. Extracts were applied topically in case of mouse ear edema $(1 \mathrm{mg} /$ ear) and administered orally in mouse carrageenan edema $(100 \mathrm{mg} / \mathrm{kg})$. These results reveal that these seaweeds and sponges have potential to be exploited as anti-inflammatory agents.

\section{Immuno-modulatory activity}

The research on immuno-modulatory natural compounds is currently gaining much attention. Seaweeds are studied for their immuno-modulatory activity as well as terrestrial plants. Surayot et al. [59] extracted sulphated arabinanas from Cladophora sp. and tested their immuno-modulatory activity using macrophages RAW264.7 on the basis of nitric oxide production (NO) and cytokines. Therefore, Cladophora sp. sulphated arabinans could have application as medicine and biofunctional compounds when cancer is increasing day by day.

\section{Hepatoprotective effects}

Hepatitis is one of the major problems of liver which disturbs its normal functioning. It could be induced by some microorganisms, or viruses or by chemical intoxicants. Ulvae lactuca polysaccharide extract was tested against a chemo-induced hepatitis in rats where galactosamine was used @ $500 \mathrm{mg} / \mathrm{kg}$ body weight [31]. Electron microscopy (EM) was used to track the ultrastructural alterations in liver tissues after treating with galactosamine and ulvan. Liver damage in galactosamine induced hepatitis was observed by significant changes in serum lipid profile, hepatic protein thiols contents and non-enzymatic anti-oxidants of tissues. Ulvan treated rats were observed to be saved from any abnormality of the microsomal enzymes and TCA, and less severe changes in mitochondria were found. In case of urea cycle enzymes, no effective prevention was seen in the pretreated rats. It was suggested that the presence of sulfated polysaccharides might have protected the functionality of microsomal membrane and mitochondria that normalize the galactosamine induced oxidative stress. 


\section{Anti-hyperlipidemic activity [60]}

Hyperlipidemy is considered one of the risk factor in cardiovascular diseases. Hot water extraction was made to get ulvan from Ulva sp. and precipitated using ethanol. A group of 50 ICR (a kind of albino mice) were treated with ulvan by oral feeding and their plasma lipid level was noticed [60]. Albino rats were used as in vivo model and were fed with ethanolic-precipitated polysaccharides for 21 days. Control group was treated with a reference drug named as Lapitor (Atorvastatine Ca). Ulvan treated rats were found lower in serum total lipids and triglycerides, total cholesterol, LDL (lowdensity lipoprotien) and VLDL (very low density lipoprotein) levels. On other hand, reduced glutathione and total thiol was also observed, suggesting ulvan as a potent agent against induced hypercholesterolemic conditions.

\section{Anti-cancer activity. Antitumor activity}

The term tumor and cancer are mostly used interchangeably but not necessarily the same. Tumor refers to a mass and it has two main types, benign and malignant tumors. In cancer the tumors are second type and are dangerous but malignant are sometimes mimicked by benign and are treated accordingly. Lee et al. (2004) evaluated the methonolic extract of Ulvae lactuca in regulating the tumor genesis [64]. Water soluble portion of extract was concentrated up to $140 \mu \mathrm{g} / \mathrm{ml}$ and human leukemia cells (U 937) were treated). Interestingly, 50\% growth inhibition was observed after treatment. Biofunctional compounds isolated from alternative bioresources to treat cancer cells have become imperative for immune-pharmacological and oncotherapeutical applications. Surayot et al. [59] extracted sulphated polysaccharides from Cladophora glomerata that are reported to suppress cancer cell proliferation. According to other researchers [51], high phenol contents of Cladophora glomerata showed strong DPPH radical scavenging activity that exhibited its strength to neutralize free radicals, which can trigger cancer cells. Furthermore, in vitro activity of $C$. albida extract against a human carcinoma cell line was reported [62].

\section{Conclusion}

Promising potential applications of green algae (Ulva sp. And Cladophora sp) has been discussed. Like other green algae, U. lactuca is also a rich source of many essential bioactive fractions ranging from antioxidants and essential minerals to the highly signified and complete profiles of amino acids and fatty acids. Other than that, higher level of soluble dietary fibres make it a potential source for healthy foods and medicinal implications. The polysaccharides (ulvan) of this species have been tested for drug release, wound dressing to tissue engineering in composite with other natural or synthetic polymers. Interestingly, ulvan based structures were found cytocompatible and non-toxic in nature. In line with the current applications, further considerations should be given to develop some nutraceutical supplements. 
Acknowledgments: The authors would like to express appreciation for the financial support of the Romanian Ministry of Research - UEFISCDI, for Complex Project no. 85 PCCDI/2018, Acronym INOBIOMAR, Project code PN-III-P1-1.2PCCDI-2017-0701.

\section{References}

[1] Bocanegra A, Bastida S, Benedi J, Rodenas S, Sanchez-Muniz FJ,. J Med Food 12:236-258, 2009.

[2] Pengzhan, Y., Quanbin, Z., Ning, L., Zuhong, X., Yanmei, W., and Zhi'en, L. Journal of applied phycology 15, 21-27, 2003.

[3] Sirbu, R., Zaharia, T., Pirjol, B. S. N., et al., The Black Sea ecosystem important potential source for pharmaceutical industry, Journal of Environmental Protection and Ecology, 11(4), 1336-1348, 2010.

[4] Sirbu, R., Tomescu, A., Jurja, S., et al., Study of bioactiv pharmaceutical components from seaweeds from the Black Sea, 15-th International Multidisciplinary Scientific Geoconference (SGEM), Albena, Bulgaria, Nano, Bio and Green - Technologies for a Sustainable Future, I, 567-574, 2015.

[5] Cadar, E., Cherim, M., Studies on the physico-chemical characteristics of the marine algae ecosystem from the romanian Black, Journal of Science and Arts, 3, 717-726, 2018.

[6] Cadar, E., Mustafa, A., Tomescu, A., Cherim M., Studies regarding polluting agents in Black Sea algae, Journal of Science and Arts 1, 255-264, 2018.

[7] Cherim M., Sirbu, R., Tomescu A., Popa M. F., Cadar, E., Comparative Studies on the Physico-chemical Characteristics of Bio-materials with Collagen from Calf and Fish Skins from Black Sea, Materiale Plastice, 56(1), 179185, 2019.

[8] Sirbu, R., Stanciu, G., Cadar, E., Tomescu, A., Cherim, M., Rev.Chim. (Bucharest), 70(3), 835-842, 2019.

[9] Sirbu, R., Stanciu, G., Cadar, E., Tomescu, A., Cherim, M., Rev.Chim. (Bucharest), 70(3), 835-842, 2019.

[10] Cadar, E., Tomescu, A., Negreanu-Pirjol, B. S., Journal of Science and Arts, 3, 533-538, 2017.

[11] Sirbu, R., Negreanu-Pirjol, T., Paris, S., Negreanu-Pirjol, B.S., Jurja, S., Tomescu, A., Important bioactive compounds from marine algae potential source of pharmaceutical industry, 14th International - SGEM Conference Proceedings, Bulgaria, I, 381-388, 2014.

[12] Sirbu, R., Cadar, E., Erimia, C. L., et al., Studies on the importance of vitamins from Black Sea marine algae, 3rd International Multidisciplinary Scientific 
Conference on Social Sciences and Arts, SGEM, Bulgaria, Conference Proceedings, II, 941-948, 2016.

[13] Ortiz, J., Romero, N., Robert, P., Araya, J., Lopez-Hernandez, J., Bozzo, C., Navarrete, E., Osorio, A., and Rios, A., Food chemistry 99, 98-104, 2006.

[14] Lahaye, M., and Jegou, D. Chemical and physical-chemical characteristics of dietary fibres from Ulva lactuca (L.) Thuret and Enteromorpha compressa (L.) Grev. Journal of Applied Phycology 5, 195-200, 1993.

[15] Wong, K., and Cheung, P. C. Nutritional evaluation of some subtropical red and green seaweeds: Part I-proximate composition, amino acid profiles and some physico-chemical properties. Food Chemistry 71, 475-482, 2000.

[16] Sirbu, R., Zaharia, T., Bechir, A., Lilios, G., Nicolaev, S., Characterisation of marine habitats ecosystem and the macro-algae biodiversity along the romanian black sea shore, Journal of Environmental Protection and Ecology, 13(1), 190-197, 2012.

[17] ***, European Pharmacopoeia $8^{\text {th }}$ edition, Council of Europe, Strasbourg, 2014

[18] *** - Romanian Pharmacopoeia, X-th edition, Medical Ed., Bucharest, 2008

[19] Singleton, V.L., R. Orthofer and R.M. LamuelaRaventos, Analysis of total phenols and other oxidation substrates and antioxidant by means of FolinCiocalteu reagent. Methods Enzymol., 299: 152-178, 1999.

[20] Hanaa H. Abd El-Baky, Farouk K. El Baz, Gamal S.E l Baroty, Evaluation of Marine Alga Ulvalactuca . as A Source of Natural Preservative Ingredient, American-Eurasian J. Agric. \& Environ. Sci., 3 (3), 434-444, 2008

[21] AOAC. Official Methods of Analysis. Association of Official Analytical Chemists, 16th Ed., K Hlrich. Arlington, Virginia, 1995

[22] AOAC. Protein content in meat. 928.08. Official Method of Analysis (17-th.). Gaithersburg, Maryland: Association of Official Analytical Chemists, 2002

[23] AOAC. Crude Fat Determination-Soxhlet Method, Meat technology information sheet, 1-3, 2006.

[24] Rohani-Ghadikolaei, K., Abdulalian, E., Ng, W. K. Evaluation of the proximate, fatty acid and mineral composition of representative green, brown and red seaweeds from the Persian Gulf of Iran as potential food and feed resources. J Food Sci Technol 49, 774-80, 2012.

[25] Metin,C., Baygar,T., Determination of nutritional composition of Enteromorpha intestinalis and investigation of its usage as foo, Ege Journal of Fisheries and Aquatic Sciences, 35(1), 7-14, 2018. 
[26] Yaich, H., Garna, H., Bchir, B., Besbes, S., Paquot, M., Richel, A., Blecker, C., and Attia, $\mathrm{H}$. Chemical composition and functional properties of dietary fibre extracted by Englyst and Prosky methods from the alga Ulva lactuca collected in Tunisia. Algal Research 9, 65-73, 2015

[27] Wong, K., and Cheung, P. C. Nutritional evaluation of some subtropical red and green seaweeds: Part I-proximate composition, amino acid profiles and some physico-chemical properties. Food Chemistry 71, 475-482, 2000.

[28] Pérez, M. J., Falqué, E. Domínguez, H, Antimicrobial action of compounds from marine seaweed. Mar. Drugs 14(3), 52, 2016

[29] Quemener, B., Lahaye, M., and Bobin-Dubigeon, C., Sugar determination in ulvans by a chemicalenzymatic method coupled to high performance anion exchange chromatography. Journal of Applied Phycology 9, 179-188. 1997

[30] Pengzhan, Y., Quanbin, Z., Ning, L., Zuhong, X., Yanmei, W., and Zhi'en, L. Polysaccharides from Ulva pertusa (Chlorophyta) and preliminary studies on their antihyperlipidemia activity. Journal of applied phycology 15, 2127, 2003.

[31] Sathivel, A., Raghavendran, H. R. B., Srinivasan, P., and Devaki, T., Antiperoxidative and antihyperlipidemic nature of Ulva lactuca crude polysaccharide on D-galactosamine induced hepatitis in rats. Food and Chemical Toxicology 46, 3262-3267, 2008

[32] Robic, A., Bertrand, D., Sassi, J.-F., Lerat, Y., and Lahaye, M., Determination of the chemical composition of ulvan, a cell wall polysaccharide from Ulva spp.(Ulvales, Chlorophyta) by FT-IR and chemometrics. Journal of applied phycology 21, 451-456, 2009

[33] Mao, W., Zang, X., Li, Y., and Zhang, H., Sulfated polysaccharides from marine green algae Ulva conglobata and their anticoagulant activity. Journal of Applied phycology 18, 9-14, 2006

[34] Lahaye, M., and Robic,A., Structure and functional properties of ulvan, a polysaccharide from green seaweeds. Biomacromolecules 8, 1765-1774, 2007

[35] Ansari, F.A., Shriwastav, A., Gupta, S.K., Rawat, I., Guldhe, A., Bux, F., Lipid extracted algae as a source for protein and reduced sugar: A step closer to the biorefinery. Bioresour. Technol. 179, 559-564, 2015

[36] Kumari, P., Kumar, M., Reddy, C. R. K., Jha, B., Algal lipids, fatty acids and sterols. Functional Ingredients from Algae for Foods and Nutraceuticals; Domínguez, H., Ed, 87-134, 2013

[37] Grama, B.S., Chader, S., Khelifi, D., Agathos, S.N., Jeffryes, C., Bioresour. Technol. 151, 297-305, 2014 
[38] Wang, H-M. D., Li, X-C., Lee, D-J., Chang, J-S., Potential biomedical applications of marine algae, Bioresource Tech.244, 1407-1413, 2015.

[39] El-Baky HHA, Baz FKE, Baroty GSE, Potential biological properties of sulphated polysaccharides extracted from the macroalgae Ulva lactuca $\mathrm{L}$. Acad J Cancer Res 2:01-13, 2009

[40] Costa LS, Fidelis GP, Cordeiro SL, Oliveira RM, Sabry DA, Câmara RBG, Nobre LTDB, Costa MSSP, Almeida-Lima J, Farias EHC, Leite EL, Rocha HAO, Biological activities of sulfated polysaccharides from tropical seaweeds. Biomed Pharmacother 64:21-28, 2010

[41] T. Negreanu-Pirjol, B. Negreanu-Pirjol, R. Sirbu, G. M. Paraschiv, A. Meghea, Comparative studies regarding the antioxidative activity of some therapeutic marine algae species along the romanian Black Sea coast, J. Environ. Prot. Ecol., vol. 13 (3A), 1744-1750, 2012.

[42] Daniels BA (2004a) Seaweed extract composition for retardation of cardiovascular disorders and preservation of healthy cardiovascular function. US Patent US 2004/0170645 (2 September 2004) J Appl Phycol 25:407-424, 421, 2013

[43] Daniels BA (2004b) Seaweed extract composition for treatment of diabetes and diabetic complications. PCT Patent WO 2004/ 103280, 2004

[44] Castro R, Zarra I, Lamas J, Water-soluble seaweed extracts modulate the respiratory burst activity of turbot phagocytes. Aquaculture 229:67-78, 2004

[45] Leiro JM, Castro R, Arranz JA, Lamas J, Immunomodulating activities of acidic sulphated polysaccharides obtained from the seaweed Ulva rigida C. Int Immunopharmacol 7:879- 888, 2007

[46] Qi H, Liu X, Ma J, Zhang Q, Li Z, J Med Plants Res 4:2445-2451, 2010

[47] S. Iftikhar, A. ur Rahman, Y. Ihtesham, A. Shakoor, G. Zaib, Antioxidant and antimicrobial potential of Otostegia limbata L., and Ajuga bracteosa L., against pathogenic microorganisms, Int J Tech Res Appl 2 179-183, 2014

[48] V. Panayotova, M. Stancheva, D. Dobreva, Alpha-tocopherol and ergocalciferol contents of some macroalgae from Bulgarian Black Sea coast, Analele Universitatii “Ovidius” Constanta-Seria Chimie 24, 13-16, 2013

[49] Y. Yoshii, T. Hanyuda, I.Wakana,K.Miyaji, S.Arai, K.Ueda, I.Inouye, Carotenoid compositions of Cladophora balls (Aegagropila linnaei) and some members of the Cladophorales (Ulvophyceae, Chlorophyta): their taxonomic and evolutionary implication, J. Phycol. 40, 1170-1177, 2004 
[50] T. Chimsook, W. Wannalangka, Withdrawn article-effect of ultrasonicassisted extraction on phenolic content of freshwater macroalgae in northern Thailand, MATEC Web of Conferences, EDP Sciences, 2015.

[51] Laungsuwon R., Chulalaksananukul W., Journal of Science and Technology 7, 181, 2013

[52] N. Malviya, S. Jain, S. Malviya, Antidiabetic potential of medicinal plants, Acta Pol. Pharm. 67, 113-118, 2010

[53] M. Jung, M. Park, H.C. Lee, Y.-H. Kang, E.S. Kang, S.K. Kim, Antidiabetic agents from medicinal plants, Curr. Med. Chem. 13, 1203-1218, 2006

[54] WHO, About Diabetes, World Health Organization, 2014 Retrieved April 4, 2014.

[55] P. Arata, M. Ciancia, L. Kordich, I. Quintana, Anticoagulant activity of sulfated polysaccharides from the green seaweed Cladophora falklandica: Po 250, J. Thromb. Haemost. 11, 1113-1114, 2013

[56] P.X. Arata, I. Quintana, M.P. Raffo, M. Ciancia, Novel sulfated xylogalactoarabinans from green seaweed Cladophora falklandica: chemical structure and action on the fibrin network, Carbohydr. Polym. 154, 139-150, 2016

[57] Rocha, I., Ferraz, N., Mihranyan, A., Strömme, M., Lindh, J., Chemical modification of Cladophora nanocellulose to provide a non-toxic material with anticoagulant properties, Front. Bioeng. Biotechnol. Conference Abstract: 10-th World Biomaterials Congress, 2016

[58] Awad, N. E., Biologically active steroid from the green alga Ulva lactuca. Phytotherapy Research 14, 641-643, 2000

[59] Surayot, U. Hun Lee, J., Kanongnuch, C., Peerapornpisal, Y. Park, W. , You, S, Structural characterization of sulfated arabinans extracted from Cladophora glomerata Kützing and their macrophage activation, Biosci. Biotechnol. Biochem. 80, 972-982, 2016.

[60] Sherif Hassan a, *, Sanaa Abd El-Twab b,c, Mona Hetta d, Basant Mahmoud, Improvement of lipid profile and antioxidant of hypercholesterolemic albino rats by polysaccharides extracted from the green alga Ulva lactuca Linnaeus, Saudi Journal of Biological Sciences, 18, 333-340, 2011

[61] Lee, D.-G., Hyun, J.-W., Kang, K.-A., Lee, J.-O., Lee, S.-H., Ha, B.-J., Ha, J.-M., Lee, E. Y., and Lee, J.-H., Ulva lactuca: a potential seaweed for tumor treatment and immune stimulation. Biotechnology and Bioprocess Engineering 9, 236-238, 2004 
[62] AwadN. E., Ibrahim, N., Matloub, N., A Phycochemical and cytotoxic activity of some marine algae, Planta Med. 75, PE73, 2009 